\title{
O CONFINAMENTO DE VANDA: UMA LEITURA DO DISPOSITIVO
}

\begin{abstract}
Roberta Veiga *
Resumo: Através da análise do filme No quarto da Vanda e do debate com J.L Comolli, busca-se pensar o método de filmagem, o controle formal, e a violência operada nos corpos dos personagens e do espectador, como constituintes de um campo de forças: o dispositivo cinematográfico. Ao conjugar uma dimensão estética e outra política, sugere-se pela análise do dispositivo que o confinamento é um vetor de sensações e de produção de espectatorialidade.

Palavras-chave: dispositivo, confinamento, Pedro Costa.

Resumen: A través del análisis de la película En la habitación de Vanda y del debate con J.L Comolli, se busca pensar el método de filmación, el control formal y la violencia causada en los cuerpos de los personajes y del espectador como constituyentes de un campo de fuerzas: el dispositivo cinematográfico. Al conjugar una dimensión estética y otra política, se sugiere por el análisis del dispositivo que el confinamiento es un vector de sensaciones y de producción de espectatorialidad.

Palabras-clave: dispositivo, confinamiento, Pedro Costa.
\end{abstract}

Abstract: My analysis of Vanda's room and the debate with J. L. Comolli are the support to discuss the filming method, the formal control, and the violence inflicted upon the bodies of characters and spectators, understood as a power field: the cinematic device. By combining aesthetic and political dimensions, the analysis of this device suggests that confinement acts as a vector of sensations and the production of spectatorship.

Keywords: device, confinement, Pedro Costa.

Résumé Par l'analyse du film Dans la chambre de Vanda et du débat avec J.-L. Comolli, on cherche à penser la méthode de tournage, le contrôle formel et la violence opérée sur les corps des personnages et du spectateur, en tant que constituants d'un champ de force : le dispositif cinématographique. En combinant une dimension esthétique et une politique, on suggère par l'analyse du dispositif que le confinement est un vecteur de sensations et de production de spectatorialité.

Mots-clés: dispositif, confinement, Pedro Costa.

\footnotetext{
* Universidade Federal de Minas Gerais, Departamento de Comunicação Social, Programa de Pós-Gradução em Comunicação. 31270-901, Belo Horizonte, Brasil.

E-mail: roveigadevolta@gmail.com
}

Submissão do artigo: 01 de julho de 2015. Notificação de aceitação: 20 de agosto de 2015 . 
No quarto da Vanda (2000) é o segundo filme da trilogia ${ }^{1}$ do diretor português Pedro Costa, que coloca em cena os precários modos de vida dos moradores das Fontainhas. O filme é "uma crônica da demolição do bairro" (Costa, 2007b), na qual os habitantes, em sua maioria imigrantes caboverdianos, são retratados em suas práticas diárias. A vida de Vanda Duarte é insistentemente acompanhada pelo olhar de Costa: no quarto, na cama, ela repete rotineiramente os gestos de preparar a heroína e consumi-la. Os outros personagens também são toxicômanos e vivem nos miseráveis espaços da vizinhança. Como esses espaços estão sendo destruídos ${ }^{2,}$ os habitantes desalojados passam de um lugar a outro, ocupando os barracos abandonados que restam.

Ao se aproximar de Vanda e dos moradores de Fontainhas, Pedro Costa vai perseguir, rigorosamente, o que há de concreto num espaço reduzido e degradado. O resultado é um filme seco, confinante, e completamente avesso ao melodrama. Pensando nos três lados que constituem a experiência cinematográfica - o modo de realização, a obra em si, e o lugar do espectador - a questão que pode caracterizar o dispositivo do filme conjuga o método de filmagem - que passa pelo enfrentamento daquela realidade e dos sujeitos filmados -, as opções expressivas do diretor e a espectatorialidade instituída a partir daí. De que maneira o método de filmagem pode ser definido ao mesmo tempo pela abertura para o cotidiano dos moradores de um bairro em ruínas, gesto documental, e pelo controle formal e narrativo sobre a plasticidade, a temporalidade e a violência próprias daquele mundo, gesto ficcional?

\footnotetext{
${ }^{1}$ O primeiro filme da trilogia é Ossos (1997) e o último Juventude em Marcha (2006). Fontainhas é um bairro muito pobre localizado na periferia de Lisboa que abrigava um grande número de imigrantes cabo-verdianos e que na época dos filmes foi sendo desapropriado em função do desenvolvimento urbano e comercial.

${ }^{2}$ Essa prática de demolição das localidades de bairros periféricos em Portugal se deveu a medidas governamentais de expansão de vias de acesso e construção de pontos comerciais.
} 
Se No quarto de Vanda pode ser tomado como um dispositivo, ele está muito distante das caracterizações comuns de tal mecanismo com uma armadilha para o real ${ }^{3}$. Não há imposição de uma estrutura de normas fixas que criariam para o filme uma realidade a partir da qual os sujeitos envolvidos seriam constrangidos a determinadas ações. Há antes, a escolha de uma circunscrição de possibilidades, por um espaço único: o bairro de Fontainhas. A invenção do método só passa por um controle protocolar se esse é entendido não como prescrição, mas como o domínio do diretor sobre os modos de ver.

Seria ingênuo achar que Pedro Costa apenas sofre a ação das forças que vêm do real (como é ingênuo que tal premissa definiria qualquer documentário) que não há preparação de atores, ensaios e exigências por parte do diretor, quais sejam: normas que o permitam concretizar um trabalho dentro de suas crenças. Assim como não se pode acreditar que tais exigências imperaram a despeito dos sentimentos e processos das pessoas dali. Existem regras visíveis, e também uma escuta, uma disposição em acolher o ritmo daquelas vidas. Há um encontro de forças: escolhas éticas e estéticas do diretor e afectos presentes no funcionamento concreto de um mundo. O dispositivo significa muito mais esse campo conflituoso de forças pelo qual passam formas de controle do que um artifício de invenção do próprio filme. Por outro lado, o dispositivo não se isenta de um artifício explícito no rigor dos enquadramentos e da duração nas ações e pequenos gestos dos personagens que vão conformando a estética do confinamento.

No quarto da Vanda faz o espectador caminhar fora da linha que separa ficção e documentário. Jean Louis Comolli identifica bem o fenômeno que vemos operar no filme: “... esclareço que, pra mim, essas

\footnotetext{
3 "Para Cezar Migliorin (2005), em Rua de mão dupla, o dispositivo é análogo a uma armadilha, a um artifício que o diretor constrói para disparar um movimento que não existia antes como um dado, ou fato, no mundo. O que se produz com esse estratagema é um acontecimento inesperado que o artista não domina. $\mathrm{O}$ diretor constrói a armadilha sob a qual ele tem o controle, e ao mesmo tempo o mecanismo instaurado produz o acontecimento, o descontrole." (Veiga, 2008: 94).
} 
duas dimensões estão sempre conjugadas no cinema, pois 'as ficções' sempre têm uma versão documentária — os corpos filmados dos atores, por exemplo - e os documentários não cessam de contar histórias e constituir personagens." (Comolli, 2004b:159). No entanto, na visão de Comolli, o documentário possui a especificidade da inscrição verdadeira, alcançada através do registro dos corpos e da máquina num aqui e agora, que o torna capaz de escapar à lógica espetacular e atingir uma zona onde as experiências singulares e a alteridade sobrevivem. "Longe de 'toda-ficção de tudo', o cinema documentário tem, portanto, a chance de se ocupar das fissuras do real, daquilo que resiste, daquilo que resta, a escória, o resíduo, o excluído, a parte maldita" (Comolli, 2001a:101).

Pedro Costa também acredita no cinema engajado nos sentimentos e distante das maquiagens que constituem as imagens comerciais da publicidade e da moda (como ele mesmo já afirmou em entrevistas). Apesar de se dizer contrário à separação entre documentário e ficção, o diretor alega, que em No quarto de Vanda, nem para ele, nem para os personagens, tratava-se de documentário, mas um filme muito próximo da ficção, intensamente construído e controlado não só por ele, mas por todos que participaram. Ou seja, se para Costa, "um filme é sempre um documentário de sua própria realização" (Costa, 2007a:134), é porque ele é pensado como um gesto recíproco: de intervir num mundo e ser contaminado por ele. Trata-se de um método de construção da mediação entre uma vida diferente, que se impõe como um material bruto, e um cineasta, que se deixa também conduzir por ela, sem abrir mão de seu desejo, de algo de seu domínio. Em No quarto da Vanda, para que a vida surgisse em sua repetição e precariedade, o corpo do diretor se inscreveu ali, criando um jogo contingente e delicado de relações na esfera do real. É esse mecanismo instituído pela contingência de uma situação determinada em um espaço, e submetido a uma pressão do real, que damos o nome aqui de dispositivo e que conjuga, em sua gênese, ficção e documentário. 
Em No quarto da Vanda, os afectos surgem na fricção das próprias vidas e não numa realidade autônoma criada como um roteiro ou como um modo de ativação do real ${ }^{4}$. As pessoas filmadas aparecem como atores das mise en scènes próprias a seu campo social, com seus hábitos e apropriações locais. Quando isso se faz no filme é porque o diretor resguardou a diferença que funda sua relação com aquelas pessoas. Instaura-se um espaço compartilhado que, para Jacques Rancière (1996), diz respeito, ao mesmo tempo, à comunidade e à separação que está na base da política. A política se define pela partilha do sensível que se refere tanto ao que é comum, quanto ao que é diferente, determinando as inclusões e exclusões nos lugares. Trata-se de uma repartição de espaços, tempos e tipos de atividade que indicam como o comum se institui e como cada indivíduo ou grupo toma parte nessa divisão. Ao contrário do consenso, há um conflito de base estética que fundamenta a política: os modos como o sensível é disputado, ganham visibilidade e são percebidos, ditos e vistos num dado tempo. ${ }^{5}$

Já que o cinema é igualitário, filma a todos igualmente, porém como igualmente únicos e distintos, ele se funda justamente nessa tensão entre consenso e dissenso. A partilha do sensível é um substrato da política que

\footnotetext{
4 "Acreditamos que a utilização de dispositivos em produções audiovisuais recentes está ligada a um desejo de referencialidade no real contido nestas obras. Se tudo é cena, se tudo está dado para ser filmado, se 'o fundo da imagem já e sempre uma imagem'(Serge Daney) a criação de dispositivos se propõe a filmar o que ainda não existe, e só existirá quando o dispositivo entrar em ação. O dispositivo é uma ativação do real.”(Migliorin, 2005)

${ }^{5}$ Para Rancière, a base do desentendimento na política está na diferença dos registros dos falantes, suas inserções particulares na língua, nos usos e atribuições dos sentidos em função de suas formas de vida. Por isso, ele é insuperável, pois, antes de qualquer confronto de valores e interesses, há um conflito que parece ser ignorado - quando se apela à igualdade dos seres falantes, quando o mundo comum dos falantes deixa de ser entendido como vários mundos que estão em constante tensão. "A afirmação de um mundo comum efetua-se assim numa encenação paradoxal que coloca juntas a comunidade e a nãocomunidade." (1996:66) Se a estética é "o que coloca em comunicação regimes separados de expressão" (1996:66), não podemos falar de uma estetização do político nas modernas sociedades, pois a estética é seu princípio. Podemos falar de uma autonomização da estética: "A estética assim autonomizada é em primeiro lugar a emancipação das formas de representação, em segundo lugar a constituição de um novo tipo de comunidade do sensível que funciona sob o modo da presunção, do 'como se' que inclui aqueles que não estão incluídos, ao fazer ver um modo de existência do sensível subtraído à repartição das partes e das parcelas" (Rancière, 1996:68).
} 
não se dá a ver de imediato nas práticas sociais, mas precisa ser desvelada. Ao assumir seu caráter de representação, o cinema produz esse desvelamento, ou seja, marca as diferenças através do ato coletivo de ver. Mas se o cinema já é de saída político, essa dimensão é diluída, quando o desentendimento que funda a partilha dá lugar à anulação da diferença, à imposição do consenso. Por outro lado, quando o poder de filmar não se sobrepõe ao outro filmado, mas esse outro pode tomar a cena para nela inscrever seu tempo e o gesto do diretor é de, a todo custo, dar a ver essa singularidade; a partilha estética é política.

\section{Plasticidade: entre a sombra e a luz}

Em No quarto da Vanda, a crueza dos acontecimentos, a ausência de enredo, a ligação não-teleológica entre as sequências, a duração da exposição dos corpos, aproximam o filme do mito da revelação de uma realidade sem mediações. Essa sensibilidade não é dada, mas alcançada pelo diretor, justamente porque ele mantém nas escolhas formais de seu trabalho um controle evidente. Tal controle se mantém através de uma certa distância no ato de filmar: a manutenção das mesmas posições em relação aos corpos; o rigor dos enquadramentos secos e repetitivos; a fixidez da câmara; e, principalmente, a insistência nesses procedimentos.

Apesar de No quarto da Vanda não ter estrutura narrativa tradicional, o espectador é conduzido por uma história porosa e complexa, feita de acontecimentos, ações, memórias e vivências de Fontainhas. Um aspecto sutil, mas determinante da montagem, é a forma como o diretor interpõe os dois ambientes principais onde essas vidas são encenadas, e os situa no espaço maior do bairro que está sendo demolido. São dois barracões vizinhos, cenografias que ao longo do filme se alternam, se diferem e, ao mesmo tempo, se espelham e confluem. Uma oscilação de visibilidades com contrastes e reflexos sutis que gera duas ambiências. 
Ao contrário de uma montagem que opera por saltos rápidos, a interpolação ocorre entre extensas durações permitindo que cada ambiente seja experimentado na força de sua experiência temporal. Há um fluxo de tempo contínuo, muito mais próximo da maneira como experimentamos o tempo, estruturado e estruturante das atividades ordinárias do cotidiano: dos momentos de ócio, silêncios e ações menos pragmáticas.

Num espaço está Vanda Duarte e sua família: a mãe, a irmã Zita e uma criança cega. Assistimos ao cotidiano de Vanda pontuado sistematicamente pelo consumo da heroína. No quarto, ela e Zita preparam a droga, fumam e conversam. Amigos da vizinhança aparecem e compartilham a droga. Na casa da família empilham-se caixas de legumes e frutas que Vanda vende no bairro, junto com outros objetos e móveis, e com a tevê, sempre ligada. Num barracão vizinho vivem Pango, Nando e Russo, que também passam os dias consumindo heroína. O barracão vai ser demolido. Lentamente, preparam a mudança enquanto ouvem, cada vez mais alto, o barulho das máquinas e dos estrondos dos blocos de concreto jogados ao chão. O espaço dos rapazes é menor, mais vazio e pouco iluminado. Há pequenos pontos de claridade - uma vela, uma brasa de cigarro, um raio de sol que se esgueira pela janela. Não vemos bem o rosto deles. Pango é negro e Nando usa um gorro e um boné por cima, que tapa seus olhos. A câmara está próxima deles e quase sempre mantém a mesma distância. Trata-se de uma encenação tímida que parece ocupar parcela menor do filme.

Na primeira sequencia nesse ambiente, Pango está tomando banho de bacia, a cena é escura e uma pequena fresta de luz ressalta a fumaça que sobe da água quente enevoando o quadro e dificultando ainda mais a visão. Vemos apenas seus contornos. Os rapazes aparecem constantemente assim: silhuetas, vultos, sombras nas paredes. São silenciosos, falam baixo, cadenciado e lentamente. As conversas são cifradas pelas gírias próprias ao 
universo das drogas. "As bombas é que estão todas maradas. Toma lá este bico, vê lá se atinas com este bico", diz um deles.

A ambiência é carregada e a atmosfera misteriosa e impenetrável em função da imobilidade da câmara e dos movimentos lentos dos personagens, da pouca luz, da indefinição dos rostos e corpos, das conversas pausadas e cifradas. Há um peso real maior ainda: os rapazes usam heroína injetável e conversam sobre as dificuldades com a agulha, as veias, os hematomas, o ar que fica na seringa e impede que o sangue entre nela. Quase como zumbis, em atos pausados, se mostram e não se mostram. Surge daí a estranheza de uma experiência de vida precária que toca à morte.

É nesse paralelo, que a vida de Vanda se torna bem menos sombria e ocupa no filme um lugar central. Seu quarto, onde ela executa o ritual de se drogar, é mais iluminado. Apesar de a câmara permanecer imóvel, ela está sempre aberta e quase nunca se aproxima, enquadrando, na maioria das vezes, todos os personagens presentes. Vanda e Zita são expressivas. $\mathrm{Na}$ primeira cena vemos os rostos com clareza, elas falam mais alto, riem e conversam sobre várias coisas enquanto fumam, ainda que as drogas ou a miséria sejam a toada dos diálogos. Há uma família ali. A mãe cozinha, Zita costura, Vanda vende verduras, a criança canta. O telefone toca e a tevê transmite uma novela brasileira, um show de Barbara Streisand. Há elementos reconhecíveis que tornam aquele universo mais penetrável e menos distante. Vanda possui carisma e senso de humor, sua fala é sincera e segura, demonstra carinho, principalmente pela mãe. Verbaliza suas revoltas, com o país, o sistema prisional (sua irmã está presa), o pai. Quando a amiga lhe diz que foi presa, ela repete muitas vezes: "Por caldos knorr, onde é que já se viu? Levarem uma pessoa presa por caldos knorr?"

A afetividade de Vanda se estende aos amigos e vizinhos. Quando, numa conversa com Pedro, o vizinho reclama de falta de ar, ela oferece remédios e insiste maternalmente que ele os tome. Quando a casa de Pango é destruída, Vanda lhe dá abrigo e é a ela quem Russo pede para tomar conta 
de seu passarinho Mandarim. Vanda tem um papel importante para sua família e para a comunidade. Tem uma força e uma segurança visíveis, aconselha, cuida e acolhe. Ainda assim, o peso de sua história é constante, ela se droga repetidas vezes. Repetido é o gesto que insiste em sugar o pouco da vida que ali se encontra.

Os dois ambientes são mostrados em longos planos imóveis. Aos poucos, num movimento de contraste e de reflexo ${ }^{6}$, a alternância lenta vai tecendo uma profunda ligação entre os personagens e suas vidas: a proximidade dos atos e rituais que envolvem as drogas, o barulho ensurdecedor, as vidas que transitam por ali. Logo na primeira cena, Vanda pergunta a Zita se Pango já arranjou outro "cubículo". Vanda e Pango se conhecem desde a infância e compartilham o vício, a destruição das Fontainhas, e uma história de sobrevivência naquela situação de constante miséria. Próximo ao fim do filme, Pango está desabrigado, sua casa foi demolida. Um close de Vanda por trás de um véu branco cobre todo o quadro e, em seguida, um close de Pango com seu rosto negro em um ambiente escuro. Do sutil contraste entre claro e escuro, aquelas vidas parecem mais próximas.

Pango: Que eu sempre que entro aqui, penso como se estivesse em minha casa. Por isso é que eu vim te pedir um abrigo, um teto.

Vanda: E sabes que o tens. Não tens porque não queres. Comida nunca te faltou.

Pango: Claro. Comida nem um lugar para me encostar. Vanda: Mas é a vida que a gente quer é essa, vida da droga. (...)

Pango: Hoje em dia é assim. Com a vida que tens também já sabes. O que me aconteceu a mim... Aconteceu-me a mim, a ti, a outros. E a muitos mais."

(Diálogo retirado do filme)

${ }^{6}$ Refletido; indireto; devido à reflexão; efeito de luz refletida; influência indireta; reprodução; imitação; diz-se de movimento que se produz no organismo por uma excitação qualquer vinda do exterior, sem intervenção da vontade.(Houaiss, Dicionário eletrônico, versã $1.0,2001$ ) 


\section{Temporalidade: duração e enquadramento}

Em No quarto da Vanda, há longos momentos de silêncio e de puro ruído: o som da rua, das máquinas que demolem o bairro, dos muros que caem, de pessoas falando ou gritando, da tevê. Em ambos os ambientes, as conversas parecem fragmentadas, partes de assuntos que não dominamos, falas que se referem a alguém que não sabemos quem é, pedaços de vidas, cacos de histórias, e são ainda mais ininteligíveis em função do dialeto e da dicção própria àquele gueto. Muitas vezes não vemos todos personagens que participam do diálogo, de modo que quem fala pode estar fora de quadro enquanto vemos aquele que escuta. As palavras se inscrevem em uma duração e desenham a continuidade, as conexões, mesmo fracas, entre pessoas, histórias, acontecimentos e memórias. Elas carregam a fragilidade e a precariedade daquelas vidas. Em muitos momentos, remetem às ações e acontecimentos imediatos. Podem ser relativas ao ambiente - calor, frio, barulho que dá nos nervos; ao corpo — dores, ressaca, cabelo sujo; às drogas, como, por exemplo, "achastes a veia", "deixa lá dar o bafo" ou "não me dês o caldo fora!"; ou aos afazeres domésticos banais; arrumar ali, deixar aquilo, sentar, levantar. Essas falas inscrevem os personagens num aqui e agora, num tempo vivido. Parece não haver textos previamente elaborados, como se a interação emergisse das situações. Os atos de fala trazem a linguagem para o cotidiano, para a vida ordinária daqueles sujeitos. Ecarnada naqueles corpos, a linguagem reencontra a experiência.

A vida só me tem dado desprezos. Morar em casas fantasmas que outras pessoas deixaram. Estive em casas... Nem uma bruxa queria lá morar! Mas também estive em casas que valiam a pena. Eram casas que... Todas as minhas casas, que eu ocupei, eram casas clandestinas. Foram casas que as pessoas abandonaram, mas... Se estivesse lá uma pessoa de bem... Eles até não mandavam abaixo. E olha, foi assim... 
Casa atrás de casa. Já paguei mais pelas coisas que não fiz... Que pelas coisas que fiz. (Fala de Pango)

Em meio às conversas corriqueiras referentes ao que há de mais concreto, imediato ali, surgem lembranças e histórias de família, de amigos, de sofrimentos, que inserem as vidas num contexto mais amplo de exclusões sociais e misérias humanas. Ditos com naturalidade, no mesmo tom das interações banais, colhidos nas vozes e ritmos das experiências cotidianas, os relatos das misérias são desprovidos de carga dramática ou extraordinária. "Ela (Vanda) é filmada quase todo o tempo em planos fixos, bem abertos, por uma câmera que nunca se aproxima muito, não detalha, não fatia, não decupa - portanto, nada é feito para dramatizar, nem mesmo para significar ou contar" (Comolli, 2001:151).

A longa e sufocante duração nos planos fixos, fechados e repetidos, reforça o confinamento dos pequenos espaços e a quase imobilidade dos corpos. Como diria Comolli (2001a:100), parece que o filme é "atravessado, furado pelo mundo", um mundo claustrofóbico onde as mesmas atividades, os mesmos gestos, resistem ao barulho e à destruição que ilham os espaços, ao mesmo tempo em que compõe com eles uma melodia macabra. Contrárias à piedade e à compaixão, as lentes do diretor fazem da lida com a pobreza, a destruição, do corpo ou do espaço, e a solidão, uma forma de vida.

Pedro Costa permite que os corpos durem nos planos, valoriza cada enquadramento pelo qual a matéria se molda ao olhar, pelo qual cada figura humana é, ao mesmo tempo, constrangida e liberada de suas cargas, deformações e asperezas. Ele abre mão de seu poder de cortar, de impor o tempo da aceleração e do olhar administrado àquele mundo filmado, para que a cena seja tomada pelos sujeitos e a auto mise-en-scène surja. Contra o tempo do espetáculo, Costa alcança o tempo lento das figuras humanas, ali 
onde elas parecem tocar a morte - corpos esquálidos, olhos fundos, gestos repetitivos e titubeantes, falas descontínuas.

Para Comolli, a descontinuidade é o gesto de morte no cinema, pois é justamente o que o aparato técnico recalca a fim de que a reprodução do contínuo da vida se dê a ver. No filme, a descontinuidade não é imposta, mas surge da porosidade e complexidade da vida que dura na cena. Se há fragmentação nas falas, ela nada tem a ver com a ditadura dos cortes dos regimes de visibilidade da tevê, dos videoclipes, dos filmes de ação. É a duração da exposição dos corpos em suas interações e ações banais que fazem com que elas apareçam cadenciadas, repetitivas, gaguejadas. A descontinuidade surge na liberdade que o corpo filmado alcança quando apanhado na continuidade das ações, vozes e movimentos, quando o corte não vem como força de fora que violenta e desrespeita seu ritmo em prol da vontade de poder do diretor. A descontinuidade aí não é recalcada pelo aparato. O diretor filma o "trabalho de morte", na destruição pelas drogas, na repetição dos atos, no enclausuramento dos corpos.

Como não há movimento de câmara, o filme oferece a possibilidade de entrarmos nas imagens, escolhermos o que queremos reter, e de trabalharmos nossa relação com elas. Num mundo onde não temos tempo, onde somos expostos a imagens incessantes que concorrem pela nossa atenção, No quarto da Vanda revive o confinamento nos cubículos e no recorte dos quadros fixos, pressiona o olhar para reduzir o campo de visão, permitindo que a experiência da alteridade nos alcance na duração do ver. Os enquadramentos confinam, parecem adensar a carga daquelas vidas ali. Sem recurso ao melodrama, sem acesso direto ao sofrimento das pessoas, o que se sente é um acúmulo de tempo a cada enquadramento: um tempo cíclico do vício da droga (drogar-se para dormir, drogar-se para suportar a ressaca ao se levantar), um tempo repetido dos movimentos para consumir a droga, e um tempo parado, quase imóvel, dos pequenos espaços - a cama de Vanda, o pequeno barracão de Pango. 
Ao sair para as ruas, a sensação do olhar pressionado, do tempo adensado, não é aliviada. Nos estreitos becos, há sequências de planos fixos de pessoas que estão por ali em meio à destruição do bairro, espaço que outrora fora habitado: os olhos delas se dirigem enviesados para a câmara, não sabemos o que elas fazem ou para onde vão. Os planos são como fotografias e os personagens fotografados como estátuas vivas. São vidas que permanecem presas àquele lugar, àquela situação, àquela experiência.

Além da precariedade dos ambientes e dos espaços reduzidos, há redução do que se vê, busca por uma exiguidade do olhar, uma insistência em pôr em cena, repetir, durar nessa precariedade: as pálidas paredes, a cama de Vanda, o cubículo quase sem móveis de Pango, os mesmos gestos e sons. ${ }^{7}$ Nada é profuso e o filme se reduz a poucos elementos, a nenhuma explicação. É da pobreza que de fato surge a experiência. ${ }^{8}$

\section{Violência e emparedamento: o paradoxo vida e morte}

Do ponto de vista de Comolli, durar na cena é uma possibilidade para o espectador encontrar "o outro como imprevisto", a figura humana em suas asperezas e excessos, no que vai da forma ao disforme. Ao durar nas cenas em que corpos padecem, o filme atinge uma experiência do tempo e do espaço que se faz sentir no corpo, que surge no tempo circular do consumo da droga e no tempo duradouro da clausura.

\footnotetext{
7 "Nesse quadro bastante realista, bastante limitado, poucos meios, pouco dinheiro, não quero fazer coisas que transbordem para outros lados. Nesse quadro um pouco realista, eu acho, o que é difícil é ter essa concentração do real, um aspecto de uma realidade ou vários aspectos de tal maneira concentrados como os Straub, que tinham um sentido coeso, verdadeiro nos filmes deles. No meu caso ainda é difícil, realidade complexa, vasta, contraditória, dispersa. A não dispersão num filme me custa muitíssimo, com tempo vou colocando ordem nessa dispersão que eu acho que é um problema contemporâneo, essa dispersão das razões, dos porquês que se fez o filme. A razão se esvai. Há uma espécie de ponto de partida para o filme, depois dilui-se na própria dispersão, salada russa... Um cineasta como Godard sempre viveu nesse dilema: como pôr ordem na salada e mostrar a salada." (Costa, 2007b)

${ }^{8}$ Fazemos aqui uma ligação com a idéia da pobreza da experiência em Benjamin, que diz respeito à incapacidade do sujeito de ter experiência e não à pobreza material.
} 
Para viver a liberdade que lhe é dada na cena, o espectador passa pelo sacrifício de tentar se projetar num corpo que pesa e num tempo que não escorre. Sua liberdade de habitar o filme é constrangida visto que a continuidade nos planos refaz os mesmos atos. Exposto durante horas a uma vida enclausurada, pressionado a olhar os mesmos corpos em seu trabalho de morte, a olhar a intimidade do outro na sujeira, na doença, na putrefação, o espectador é levado a uma experiência de alteridade muito mais sensorial que intelectiva, seu corpo resiste ao peso daquela vida e padece também por isso.

Quanto mais as cenas duram e se repetem, mais se questiona sobre a possibilidade de continuidade daquela forma de vida, a possibilidade de sua existência. Essa possibilidade não é mais um lugar ficcional, a "missão redentora" do cinema expressa na travessia do personagem (Comolli, 2007:152). É a ilusão que se desfaz, ilusão muito maior do que o domínio da representação num filme, do que o fracasso do visível ante o "trabalho de morte" (Comolli, 2007: 152). É a ilusão da própria vida. Ao tocar em algo muito cru e real, a experiência ultrapassa os limites do engodo cinematográfico, das fronteiras entre real e ficcional, pois é experiência corpórea, sufocante, duradoura. A vida está ali de fato tocando a morte. Entre as paredes do cinema, o espectador sofre o emparedamento junto com os personagens, e não pode julgá-los.

Como diz Pedro Costa (2007a: 131), a ficção é sempre uma porta que queremos abrir, e no cinema de hoje, de Hollywood, a porta que se abre é a promessa da projeção de que o espectador se sentirá bem. O espectador quer ver a si mesmo na tela. O peso e o desafio de No quarto da Vanda está em fechar a porta para que o espectador veja a imagem, a imagem que diz “é", e nada mais. A pressão é para se ver realmente, e para isso é preciso que o espectador se mantenha à margem do filme. É preciso saber apenas ver, sem querer que o filme seja sua própria projeção. 
Comolli afirma que em No quarto da Vanda, o espectador está num falso lugar "nem 'bom' nem 'mau', deslocado, fora dos eixos, inútil talvez" (2007: 154). Na teoria do autor, o lugar da crise na espectatorialidade é esse em que os fenômenos de identificação e projeção — que se dão em função de transformações na narrativa e de ganhos e perdas que sofrem os personagens ao longo da história — não são possíveis. No quarto da Vanda contraria a "representação clássica" (Comolli, 2007: 151) pois não permite ao espectador jogar o mesmo jogo que os atores-personagens. Estamos fora desse sistema de representação, já que o filme institui-se como um "documento sobre provas vividas pelos corpos filmados durante sua gravação" (Comolli, 2007: 151). Aquele que vê é barrado e está ante uma obra que não o convida a participar da cena e a compartilhar algo dos personagens. Para o autor, essa obliteração é intensificada no filme, pois nada é dito, contado ou montado, há apenas um "quarto mortuário" onde Vanda se droga repetidamente. Nas palavras do autor, o que se passa nesse espaço "não é da ordem do olhar, manifesta ao contrário toda a impotência do olhar, o fracasso do visível diante do tempo que passa e a morte que trabalha" (Comolli, 2007: 151).

Sem espetáculo, o espectador não é aquele que vê Vanda se destruir, mas quem vê algo que se "oferece sem se dar a ver" (Comolli, 2007:151). Ou seja, o gesto lento da morte é o que se oferece e ao mesmo tempo não pode ser visto. $\mathrm{O}$ trabalho de morte está na repetição incessante do gesto de consumir a droga, na demolição do bairro, no enclausuramento de Vanda no quarto e na duração nas mesmas cenas. Formas de constrangimento a que os moradores de Fontainhas estão submetidos. Características que definem a cena constante do filme: o dispositivo de Costa. Para Comolli, esse trabalho ressalta a condição maquínica do cinema, o cinema como máquina de registro, de contagem do tempo. Sua versão descontínua, analítica, de fragmentar e repetir o movimento. Se a prisão está em toda parte e o constrangimento do tempo e espaço não se abre para que a personagem se 
ofereça à significação ou ao testemunho, para o autor, é impossível ao espectador projetar ali qualquer tipo de sentimento. Ele está "perturbado" pela cena que insiste em se repetir, e que não abre espaço para salvar aquela que se destrói. Vanda não tem desejo de se livrar das drogas. Prevalece a indiferença da personagem em relação a sua destruição e a indiferença da câmara de Costa àquele ato terrível.

Nada resta ao espectador diante da recusa da evolução, do progresso, da terapia, do salvamento. Para Comolli, por ser demasiadamente humana, Vanda é inútil para aquele que vê, sem finalidade ou uso. Tal indiferença, a princípio sempre falsa no cinema — pois filmar seria, de saída, conferir uma interpretação a algo, uma fabricação — para o autor é alcançada em No quarto da Vanda, uma vez que o ritual da droga desafia a narrativa e o drama, o cinema enfim. Por isso, o autor associa a câmara de Costa à câmara de vigilância que nada deseja e que é insensível ao sofrimento do outro. Eis o gesto de morte.

Diante de nós (que não podemos fazer nada, a não ser assistir sem esperança de assistência, como o próprio cineasta tendo renunciado à toda 'intervenção' portadora de sentido porque seria demasiadamente plena de sentido), o quarto se esvaía da presença de Vanda que é como um desafio mudo e cego a toda presença, no sentido forte dessa palavra no cinema. (Comolli, 2007: 152).

O lugar do espectador seria então falso, não-lugar onde nada pode ser partilhado. Se Vanda não muda, não há espaço para o espectador, ele não se encontra ali, por isso sobra, “é espectador em demasia" (Comolli, 2007: 152). A partilha possível através da perda, por exemplo, torna-se impossível, pois Vanda de fato vive a condição que a leva a morte. Mas ao mesmo tempo, Comolli confere ao espectador um lugar "entre" o ser e o não-ser, entre a vida e a morte. Concordamos que o espectador do espetáculo é frustrado e barrado em seu desejo de participar da cena. Não há espaço para 
o imaginário quando a clausura não é só aprisionamento no espaço, mas no ritmo da vida, no gesto que se repete, na indiferença de um corpo que se oferece a câmara. Porém, se seguirmos o raciocínio do autor de que Vanda é a recusa da transformação, a indiferença nela mesma, na qual conta apenas o trabalho de morte, trabalho maquínico do cinema, há de fato uma impossibilidade de jogo ou da partilha. Mas na medida em que aquilo que barra o espectador é de uma força tal que não há jogo, como é possível falar num lugar "entre" o jogo e o não-jogo? Se o lugar "entre" é um entre dois, onde está nesse par antinômico, o primeiro: o jogo?

Talvez Comolli esteja assumindo o jogo como um a priori do cinema, aquilo que é esperado pelo espectador no momento em que ele entra na sessão, o que constitui sua condição de espectador. Então estar entre o jogo e o não-jogo não é algo que o cinema e não o filme em si oferece. Por outro lado, se o filme não reinstitui o jogo, se não há participação na cena, e nenhum sentimento se constrói, há cinema? O que engajaria o espectador para persistir vendo? Se Comolli admite que o espectador está entre o sentido e o não sentido, entre o ser e o não-ser, perguntamo-nos onde está o sentido, o ser, se o autor na verdade ressalta apenas a morte, o não-ser, a recusa do filme em engajar o espectador. Se não há partilha de sentido, o cinema está fora do homem, perdeu-se como experiência.

Sabemos que não é esse o lugar para onde Comolli quer conduizir seu argumento. Ele afirma que a partilha é impossível, mas afirma também que ela existe na medida em que Vanda é quem nos partilha e nos dilacera. Então há afectos, somos afetados pelo filme. Encontramos aí a possibilidade desse espaço "entre" que pressupõe de imediato que o filme ao mesmo tempo concede e recusa algo ao espectador. Pensamos no outro lado que não é sombra, noite, mas luz, dia. Pensamos a "vanidade" de Vanda como forma de vida. Para Agambem (2000b), nenhuma vida pode ser separada de sua potência, a vida nua não pode ser isolada, ela "é" o viver, a imanência, sempre aberta a formas de resistência e fluxo. 
Ao contrário do que diz Comolli, esse lugar "entre" do espectador não poderia ser falso. Os termos falso e verdadeiro, bom e ruim, não parecem se adequar aí. Um lugar que dificulta um julgamento não é falso por oscilar entre possíveis. Talvez a melhor pergunta seja: o que se passa não é da ordem do ver (como o ver do espetáculo)? A despeito de participar ou não da cena, é possível ao espectador apenas olhar? É possível uma relação com o ver que passe pelo olhar sem julgamento, sem identificação plena? Ver não é consumir aquelas vidas, mas ser conduzido pela imanência do viver (vive-se), deixar-se atravessar pelos afectos. Se é possível estar num "entre", lugar legítimo para o espectador, é porque os embates entre a narrativa e o repetir-se, entre o drama e a não-significação, precisam ser melhor equacionados. Por mais fragmentada que seja, há narrativa no filme, seja por aquilo que os personagens dizem sobre suas condições de existência, seja pela montagem que permite a construção de uma história, ainda que frágil e precária. Essa história se faz nas relações entre Vanda e Pango, Vanda e a mãe, Vanda e Zita; Zita no hospital, Vanda na comunidade, Pango e sua relação com a droga. O bairro está sendo demolido, Vanda vende verduras, a mãe cozinha, Pango prepara sua mudança. Por isso é possível jogo.

Para Comollli, Vanda expressa a recusa de sentimentos, quando talvez seja preciso perceber nos intervalos entre os momentos em que ela se droga, aqueles em que partilha sua vida com os outros, representando um elo na comunidade. Assim, os personagens expressam sentimentos por ela que produzem afeto no espectador. A opção pelo ritual de drogar-se é manifestação ordinária ali, inscreve-se como forma de vida no filme. A indiferença não dá conta de todo o filme, ela é atravessada por elos frágeis que compõem as histórias, que permitem, inclusive, que se fale de "trabalho de morte" e não da morte como fim. É porque há vida numa experiêncialimite de estar próxima da morte que o espectador se situa nesse "entre", que é um lugar difícil, oscilante, exigindo do espectador outra relação com o 
ver. Se o espectador sobra, se o que se lhe oferece é pouco, é justamente porque seu lugar não é o do controle, mas o do deixar-se olhar e ser levado.

Estar entre vida e morte, luz e sombra, é possível porque o trabalho lento da morte se impõe como obliterarão do ver, ao mesmo tempo em que a luz pouca que se esgueira nas frestas dos cubículos afirma uma existência, mais ainda: afirma uma experiência. Na esteira de Agamben (2005: 25), Vanda talvez queira se desvencilhar de toda experiência ao drogar-se. Porém, uma vez que tal experiência a aproxima da morte, limite da experiência, é ali que o olhar se fixa e se adere. Ali mesmo, a impotência do espectador aponta para um outro lugar do cinema que não é o da transformação, das perdas e ganhos dos personagens, mas do devir. Vanda e seus vizinhos nos tocam, tanto como afetividade, o comum da vida partilhável no simples fato de viver, quanto nos afectos, essa força da qual não podemos falar, não sabemos julgar.

Para Comolli, Vanda esvazia o espaço do quarto. A repetição do ato de drogar-se torna-se um gesto maquínico. Mas o desejo pela droga está impregnado no espaço. O quarto guarda os vestígios da experiência-limite: o cobertor engordurado e puído em que Vanda escarra, limpa o nariz, deixa cair o pó da droga; a fumaça constante, as paredes descascadas, o saco de isqueiros, as pessoas que entram e saem, que convivem ali com ela. Parece que o paradoxo vida e morte coloca o espectador nesse entre, como esse caminho lento que se oferece a ver mas que oblitera a visão. Comolli afirma que o espectador é solicitado a confrontar o outro filmado. Ora, não seria essa solicitação uma forma de engajamento na vida, no sentido do ser? Como dizer que Vanda é sem uso para o espectador, como esperar uma assistência, ali onde só há inutilidade? Talvez o lugar vazio e falso do espectador seja o da presença de um cinema que não é mais assistencialista e dramático, bom ou mau, mas que implica o espectador num campo de forças bem mais complexo do que aquele no qual a identificação é a entrada. O quarto só é uma clausura porque está preenchido de vida, seja ela 
qual for. Se, como diz Comolli, "pertencemos a Vanda" (2007: 153) é porque também somos emparedados ao longo do filme.

A clausura ao extremo leva à consciência de um poder biopolítico que controla a todos, e do qual eu, espectador, de alguma maneira também sou vítima. Não "estou fora do lugar do espectador" (Comolli, 2007: 152), estou fora do lugar do espectador do espetáculo que consome vorazmente imagens e vê seu desejo satisfeito nas telas; fora do espectador dos programas de reality shows que crê controlar a vida dos outros porque os vigia, que goza com a intimidade do outro, que quer ver mais aquelas vidas assépticas. Assim como nada muda, meu lugar de espectador também é o mesmo, não muda, e manter-se nele é o aprendizado do ver, do saber ver para além de mim, o outro. Por isso, não sou "espectador em demasia" (Comolli, 2007:152), mas, parafraseando Godard, ${ }^{9}$ sou justo um espectador de uma vida qualquer.

No filme, o dispositivo que confina personagens, diretor e espectador não é uma invenção estratégica ou uma escolha, mas um encontro e um embate com o confinamento. É como se a imagem estivesse sempre aquém de uma vida por demais confinada, que os meios audiovisuais não podem inventar, nem simular. Se, como diria Comolli (2001a), algo do real resta ali, ele já é pura clausura, na repetição dos pequenos atos diários que se impõem como mandamentos e constrange a vida em seus cubículos.

A própria precariedade já é o constrangimento maior que impõe uma vida enclausurada, emparedada, já que o que mais vemos são as paredes, cinzas, beges, descascadas, sem cores, imagens ou figuras, com poucas janelas, que não se abrem para um horizonte, mas para outros espaços menores, para pedaços de muros (entulhos e detritos), onde há apenas poucos feixes de luz e a sombra se sobrepõe. A situação social mais ampla a

9 "Godard tem uma bela fórmula: não uma imagem justa, justo uma imagem. (...) 'justo ideias' é próprio do devir-presente, é a gagueira nas ideias; isso só pode se exprimir na forma de questões, que de preferência fazem calar as respostas. Ou mostrar algo simples, que quebra todas as demonstrações." (Deleuze, 1992:53). 
que os personagens estão sujeitos, a realidade crua da exclusão, está em toda parte, não roteirizada, não explicada, mas sentida pelo real que a imagem ao mesmo tempo não dá a ver de todo, mas aponta sem cessar por tons, ambiências, atos e ritmos claustrofóbicos.

Na Antiguidade e na Idade Média, as pessoas eram emparedadas, condenadas a viver, resistindo até a morte, nos escuros de pequenos vãos entre paredes. Conta-se que na Roma Antiga as vestais, moças virgens que perdiam a pureza, eram confinadas a cubículos onde morriam de fome ou asfixia. Trata-se do homo sacer, ${ }^{10}$ a vida que não pode ser sacrificada, mas que se pode matar. Nos campos de concentração, judeus eram entulhados em espaços escuros e reduzidos, mortos nas câmaras de gás: vida nua que podia ser eliminada. De um lado, a soberania inquestionável, de outro o poder da biopolítica. Ali, no quarto da Vanda, a vida está no próprio emparedamento, não há saídas, ela pode existir só ali, é uma vida quasemorte. Enquanto há paredes que não foram demolidas, circunscrevendo pequenos espaços, ainda vemos Vanda, Pango e seus vizinhos em seus modos de vida.

Essa experiência-limite do emparedamento está em Vanda completamente determinada pela droga, pois o que vemos na clausura é sua relação diária com as drogas: sua tosse compulsiva, os repetidos escarros, sua voz rouca, pilhas de isqueiros testados e acesos, catálogos de telefone, abertos e folheados para que o pó da droga seja raspado e usado, uma, duas, muitas vezes. Se a vida é uma quase-morte, ao mesmo tempo resiste à morte. Se o ato que se vê, incessantemente, é o de se drogar, Vanda sobrevive é na droga. Paradoxo vida-morte. Aquilo que a exclui dos códigos da normalidade é o que a inclui numa forma de vida qualquer, uma bios que nasce na clausura.

\footnotetext{
${ }^{10}$ Conferir Agamben, 2002.
} 
No dispositivo de Pedro Costa, a droga não é linha de fuga que permite Vanda e outros moradores alcançarem um fora dali. Ao contrário, a droga constitui aquele confinamento, assegura a existência. Nós, espectadores, não vemos as "viagens" de Vanda após consumir a droga, não estamos com ela em outro lugar ao qual a droga a levaria, nem a outra sensação, de prazer, liberdade ou êxtase; ao contrário sempre estamos ali, no quarto, na cama, nas repetidas vezes que o consumo se dá. Vemos acontecimentos concretos, atos corporais, a presença física da personagem - que tem os olhos amarelados envoltos por uma órbita vermelha, o rosto pálido e molhado de suor. Ela escarra na cama e dobra a colcha encardida e ensebada por cima do líquido que expeliu. Ela se cobre e cantarola seu frio: "estou com frio, frio, frio...". Outro dia, acorda, tosse, escarra, vomita, soa o nariz na colcha, e novamente se droga pra aplacar a ressaca constante, num ciclo que se repete. Em meio a poucos e curtos diálogos, passa grande parte do tempo na cama, cumprindo os movimentos repetitivos que a levarão a se drogar.

Nada muda com a droga, ao contrário, ela é parte da rotina de Vanda, pontuando-a com sua presença sempre reiterada. Mais ainda: a droga torna Vanda mais presente e carnal, próxima da morte, mas viva a nossos olhos, pois é o ritual que ela cumpre várias vezes ao dia, os movimentos mínimos que executa, o que pontuam sua presença na imagem. Acompanhar a vida de Vanda é esperar por esses momentos como parte de sua subjetividade.

Se o dispositivo se instaura no paradoxo vida e morte, é justamente porque a força de evidência do visível não pode ser apagada, nela está a vida de Vanda resistindo ali, no interior da prisão. A duração dos planos, a valorização dos enquadramentos, a exiguidade, a fixidez da câmera, enfim o confinamento que dá a ver a violência, o ruído, a sombra, o trabalho de morte, também acolhe a resistência, a palavra, a luz, uma vida. É a dupla face da biopolítica de que nos fala Foucault (1998): o poder que incide sobre a vida rouba sua potencialidade e a conforma, cria resistência, ou seja, 
outras formas de subjetivação. Assim como o cinema não consegue constranger por completo os corpos e a vida, por mais que a reduza e a modele, o poder também, para Foucault, vai, ao controlar, sempre criar o contra-poder, brechas por onde se esgueira o descontrole e o impensável. É de dentro do dispositivo que dá a ver o mundo em sua dimensão mais claustrofóbica que uma forma de vida qualquer se insinua.

\section{Referências bibliográficas}

AGAMBEN, Giorgio (2005), Infância e história. Destruição da experiência e origem da história, Belo Horizonte: Editora UFMG. (2002) Homo Sacer. O poder soberano e a vida nua I, Belo Horizonte: Editora UFMG.

COMOLLI, Jean-Louis (1975), "Técnica e ideologia" in Revista de cinema. n.1. agosto/setembro, Porto: A regra do jogo edições. (Textos traduzidos dos Cahiers du Cinéma n. 229, 230, e 321). (2001a), "Sob o risco do real" in Catálogo forumdoc.bh.2001, (5 festival do Filme Documentário e Etnográfico), Belo Horizonte. (2001b), "Cinema contra espetáculo" in Catálogo forumdoc.bh.2001, ( $5^{\mathrm{a}}$ festival do Filme Documentário e Etnográfico), Belo Horizonte. (2004a) Voir et Pouvoir. L'innocence perdue: cinema, télévision, fiction, documentaire. Paris: Éditions Verdier. (2004b) "Não pensar o outro, mas pensar que o outro me pensa" in Revista Devires - Cinema e Humanidades. Belo Horizonte: Universidade Federal de Minas Gerais. Faculdade de Filosfia e Ciências Humanas (Fafich), v. 2., n.1. (2007) "O anti-espectador" in Catálogo forumdoc.bh.2007, (11 festival do Filme Documentário e Etnográfico), Belo Horizonte. 
O confinamento de Vanda ...

COSTA, Pedro (2007a), "Uma porta fechada que nos deixa a pensar" in Catálogo forumdoc.bh.2007, (11 ${ }^{\mathrm{a}}$ festival do Filme Documentário e Etnográfico), Belo Horizonte.

(2007b), Entrevista em áudio concedida a Daniel Ribão. Produção Procurarte - associação cultural e social e Filmes de Quintal.(encarte) in Catálogo forumdoc.bh.2007 (11 a Festival do Filme Documentário e Etnográfico), Belo Horizonte.

DELEUZE, Gilles (1992), Conversações, Rio de Janeiro: Ed 34.

FOUCAULT, Michel (1998), História da sexualidade I: a vontade de saber, Rio de Janeiro: Edições Graal.

MIGLIORIN, Cezar (2005), O dispositivo como estratégia narrativa. Disponível em: http://www.estacio.br/graduacao/cinema/ digitagrama/numero3 /cmigliorin.asp

RANCIÈRE, Jacques (1996), O desentendimento. Política e filosofia, São Paulo: Ed 34.

VEIGA, Roberta (2008), A estética do confinamento: o dispositivo no cinema contemporâneo, Tese de doutorado, PPGCOM, FAFICHUFMG. 